\title{
Androgenic response of wheat genotypes resistant to fusariosis
}

\author{
Mônica Bossardi Coelho(1), Sandra Maria Mansur Scagliusi(2), \\ Maria Imaculada Pontes Moreira Lima(2), Luciano Consoli(2) and Magali Ferrari Grando ${ }^{(1)}$
}

(1)Universidade de Passo Fundo, Faculdade de Agronomia e Medicina Veterinária, BR 285, Km 292, São José, CEP $99052-900$ Passo Fundo, RS, Brazil. E-mail: monicabossardicoelho@hotmail.com, magali@upf.br (2)Embrapa Trigo, BR-285, Km 294, Caixa Postal 3081, CEP 99050-970 Passo Fundo, RS, Brazil. E-mail: sandra.scagliusi@embrapa.br, maria-imaculada.lima@embrapa.br, luciano.consoli@embrapa.br

\begin{abstract}
The objective of this work was to assess the androgenic response, via microspore culture, of wheat genotypes with different levels of resistance to Gibberella zeae. The number of androgenic embryos per spike, and of green and albino plants was counted for the BRS 179 (moderately resistant), Frontana and Sumai 3 (resistant), and BRS 194, Embrapa 27, and Fielder (susceptible) genotypes. The degree of interference by the Fielder, Pavon 76, and Sumai 3 ovary-donor genotypes, used for co-culture with the microspore cells, was also assessed regarding androgenic response. Induction efficiency ranged from 0.33 embryo per spike for Embrapa 27 to 109.8 embryos for Frontana. Sumai 3 presented the second best response, and Embrapa 27 behaved as highly recalcitrant. The co-culture of ovaries from the Fielder genotype stands out from the others and positively interferes in the embryo induction rate. No significant differences were observed for the regeneration frequency of green plants; however, for albino plants, BRS 194 produced the highest rate. Frontana and Sumai 3 present the highest androgenic response rates and can be used in breeding programs for the rapid development of cultivars resistant to Gibberella zeae.
\end{abstract}

Index terms: Gibberella zeae, Triticum aestivum, doubled haploids, microspore.

\section{Resposta androgênica de genótipos de trigo resistentes à fusariose}

\begin{abstract}
Resumo - O objetivo deste trabalho foi avaliar a resposta androgênica, via cultura de micrósporos, de genótipos de trigo com diferentes graus de resistência à Gibberella zeae. Contou-se o número de embriões androgenéticos por espiga, e de plantas verdes e albinas para os genótipos BRS 179 (moderadamente resistente), Frontana e Sumai 3 (resistentes), e BRS 194, Embrapa 27 e Fielder (suscetíveis). A interferência dos genótipos doadores de ovários Fielder, Pavon 76 e Sumai 3, utilizados para cocultivo das células de micrósporos, também foi avaliada na resposta androgênica. A eficiência de indução variou de 0,33 embrião por espiga para Embrapa 27 a 109,8 embriões para Frontana. Sumai 3 apresentou a segunda melhor resposta, e Embrapa 27 se comportou como altamente recalcitrante. O cocultivo de ovários do genótipo Fielder se destaca dos demais e interfere positivamente na indução dos embriões. Não foram observadas diferenças significativas para a regeneração de plantas verdes; no entanto, para plantas albinas, BRS 194 produziu as taxas mais altas. Frontana e Sumai 3 apresentam as mais elevadas taxas de resposta androgênica e podem ser explorados em programas de melhoramento para o rápido desenvolvimento de cultivares resistentes à Gibberella zeae.
\end{abstract}

Termos para indexação: Gibberella zeae, Triticum aestivum, duplo-haploides, micrósporos.

\section{Introduction}

Brazil is recognized worldwide as a reference for agribusiness and for its ability to compete in a variety of agro-industrial chains. However, wheat (Triticum aestivum L.), one of the principal raw materials of the food industry, continues to be imported from other countries, as its output is insufficient to meet the needs of the internal market, causing great financial losses. Another exacerbating factor is the susceptibility of this crop to substantial damage by several pathogens, which results in important phytosanitary setbacks (Jesus Junior et al., 2011; Oliveira Neto et al., 2017).

Among the global issues faced in wheat culture, gibberella or fusariosis, emerges as the main one. The etiological ascomycete agent of this disease is Gibberella zeae (Schwein.) Petch (1936), which, in its imperfect phase, corresponds to Fusarium graminearum. The disease severely affects productivity and grain quality, besides causing health issues due to mycotoxin contamination, which has adverse effects both on animals and humans (Niwa et al., 2014). 
As this is a hard-to-contain disease, steps to help reduce economic losses and potential health risks include crop rotation, chemical treatment with fungicides, and implementation of management methods to decrease the inoculum source. In this context, host genetic resistance appears to be the most practical and successful means of control (Nishio et al., 2016).

Although moderately resistant wheat cultivars are available, their degree of resistance is inadequate for effective disease control. Genetic resistance to fusariosis is of the quantitative or polygenic type, in which several genes exert small effects (Parry et al., 1995), making it difficult to combine a resistant material with suitable agronomic features. Therefore, it is necessary to provide breeding programs with tools that contribute more quickly and efficiently to the development of new varieties expressing disease resistance.

Over the past years, introgression of resistant genes has been used in breeding programs to reduce the impact caused by major diseases. However, when the conventional approach is adopted for this procedure, successive self-fertilization cycles are needed until the resistant quality is completely integrated into the new genotype, which takes a very long time. Unlike the conventional procedure, fully homozygous lines can be produced in a single generation via the in vitro production of haploid plants with subsequent genome duplication, which enables the desirable genotypes to be selected faster, allowing progress in the development of new cultivars. Haploidization, besides speeding up breeding programs, can also be applied to other significant areas of research, such as genetic manipulation and production of genetically modified organisms. Furthermore, it can be an effective tool in the generation of materials for gene function analysis for the development of genetic mapping populations, being beneficial for economically significant crops like wheat (Dunwell, 2010; Lantos et al., 2013).

Since the 1970s, the use of haploid plants through gametic embryogenesis has been reported for basic and applied genetic studies on more than 250 plant species from 100 genera and 40 different families (Germanà, 2011). However, several factors still hinder the success of obtaining haploids, which may vary depending on the method chosen and, especially, on the interaction with the tested genotypes.
Of the approaches described for producing doubledhaploid wheat plants, the following three are the most commonly used: intergeneric hybridization, anther culture, and isolated microspore culture (Germanà, 2011; Lantos et al., 2013). As each method has its own specific benefits and constraints, it is necessary to know the response of each genotype to the method chosen for haploid production. Isolated microspore culture shows advantages such as the exclusion of the emasculation and pollination steps during intergeneric hybridization, the improvement of the rates of spontaneous chromosome doubling, and the non-interference of maternal anther tissues on microspore cells (Maheshwari \& Eudes, 2015; Lu et al., 2016). However, several factors strongly affect the effectiveness of microspore culture, including the physiology of donor plants, spike stress treatments, exogenous factors as ovary co-culture, and, most importantly, the genotype of the microspore donor plants (Lu et al., 2016). Future findings will allow improvements in wheat breeding programs, such as the inclusion of resistant genes through the use of the doubled-haploid technology.

The objective of this work was to assess the androgenic response, via microspore culture, of wheat genotypes with different levels of resistance to Gibberella zeae.

\section{Materials and Methods}

All experiments were performed at Embrapa Trigo, located in Passo Fundo, in the state of Rio Grande do Sul, Brazil $\left(28^{\circ} 15^{\prime} 46^{\prime \prime S}, 52^{\circ} 24^{\prime} 24^{\prime \prime} \mathrm{W}\right)$. Wheat seeds were obtained from Embrapa Trigo, and the genetic materials were selected based on their degrees of resistance (BRS 179, Frontana, and Sumai 3) and susceptibility (BRS 194, Embrapa 27, and Fielder) to fusariosis, as well as on their known responses to androgenesis (Embrapa 27 and Fielder, considered recalcitrant and responsive, respectively). Among the assessed genotypes, Frontana and Sumai 3 stand out as universal sources of material resistant to fusariosis (Niwa et al., 2014).

The seeds were subjected to chemical treatment using an insecticide and fungicide solution (Imidacloprid $600 \mathrm{~g} \mathrm{~L}^{-1}$ : Triadimenol $150 \mathrm{~g} \mathrm{~L}^{-1}$ ), at a 1:1 ratio, which was spread on water-moistened Germitest paper, placed in a beaker, and maintained at $4^{\circ} \mathrm{C}$ in the dark, 
for four days. Then, the Germitest paper with the seeds was transferred to the growth chamber for one week, at $24^{\circ} \mathrm{C}$, with a 16 -hour photophase. Three plants were grown per 7-L pot filled with a homogeneous mixture of soil, vermiculite, and substrate (1:1:1). The pots were placed in the PGR36 plant growth chamber (Conviron, Manitoba, Winnipeg, Canada) with the following controlled conditions: temperature of $18 \pm 2^{\circ} \mathrm{C}$ (day) and $14 \pm 2^{\circ} \mathrm{C}$ (night), photophase of 16 hours, and relative humidity of 70 to $80 \%$; Hoagland nutrient solution was provided every week. The first ten spikes of each genotype were collected at stage 45 on the Zadoks scale (Zadoks et al., 1974), when microspores were in the uninucleate developmental phase (intermediate or late), which was identified by viewing the anthers removed from the middle of the spike on a light microscope (Jähne \& Lörz, 1995). Five spikes were collected from each plant at a later developmental stage - stage 57 on the Zadoks scale to be used as ovary donors, since co-cultivation with ovaries was found to enhance regeneration efficiency (Broughton, 2008; Castillo et al., 2015).

All collected spikes were wrapped in foil sheets and maintained for three weeks under refrigeration, at $4^{\circ} \mathrm{C}$, in glass vials containing deionized water. To determine the effect of the ovary-donor genotype on androgenic response, ovaries from Fielder, Pavon 76, and Sumai 3 were used for co-culture with microspore cells (Liu et al., 2002). The spikes were subjected to cold pretreatment to induce young microspore cells to exhibit their totipotent capacity and modify their original genetic developmental route, from the gametophytic to sporophytic pathway.

The isolation and culture of microspores were performed based on the protocol established by Scagliusi (2014), with minor modifications. After the cold pretreatment, leaves and awns were removed and the spikes were washed for $10 \mathrm{~min}$ in an autoclaved vessel containing one drop of Tween 20 in $1 \mathrm{~L}$ sterile water and $10 \%$ bleach ( $2.5 \%$ sodium hypochlorite). Then, the spikes were washed five times in sterile deionized water. In each extraction process, the aseptic spikelets obtained from ten spikes were transferred to a Waring autoclaved blender with a mini-sample container (Waring Laboratory Science, Torrington, CT, USA) in $40 \mathrm{~mL}$ NPB 99 liquid extraction medium (Liu et al., 2002), maintained at $4^{\circ} \mathrm{C}$. The spikelets were blended twice at a low speed of $7 \mathrm{~s}$ each time.
The extract was first filtered through an autoclaved stainless steel sieve and then through a $100-\mu \mathrm{m}$ pore filter. The filtered solution was divided and poured into two 50-mL tubes. Samples were centrifuged at $100 \times g$, for $5 \mathrm{~min}$, at $4^{\circ} \mathrm{C}$, and the microspores were pelleted. After discarding the supernatant, the microspores were placed into a single tube, resuspended in $35 \mathrm{~mL}$ NPB 99 liquid extraction medium, and subjected to a second spin cycle. Next, two new centrifugation cycles were carried out, and the pellet was dissolved in $2 \mathrm{~mL}$ NPB 99 liquid medium. The suspension containing the microspores was carefully poured into a sterile maltose solution $(20 \% \mathrm{w} / \mathrm{v})$, and the final pellet containing the purified cells was obtained after the last centrifugation was completed. The cells were resuspended in $1 \mathrm{~mL}$ NPB 99 liquid extraction medium, and their concentration was determined using a mirrored Neubauer chamber. After being counted, the cells were diluted in a semi-solid medium - NPB $99+10 \%$ Ficoll $+10 \mathrm{mg} \mathrm{L}^{-1}$ gum arabic (Merck \& Co., Inc., Kenilworth, NJ, USA) -, and their concentration was then adjusted to $7-8 \times 10^{4} \mathrm{~mL}^{-1}$. The microspore suspension was distributed into $30-\mathrm{mm}$ Petri dishes, where ten ovaries aseptically taken from the more mature spikes were placed. The $30-\mathrm{mm}$ Petri dishes were sealed with parafilm, then transferred onto larger $150-\mathrm{mm}$ Petri dishes containing a small open plastic dish inside, with sterile water to keep humidity up; it was also sealed and incubated in the dark at $27^{\circ} \mathrm{C}$ for up to 40 days. Using inverted light optical microscopy, the purified cells were monitored to verify the beginning of cell divisions. Every day, the embryogenic structures were observed to confirm their gametic origin. Approximately 1-mm-sized embryos were aseptically moved to $100-\mathrm{mm}$ diameter Petri dishes containing $20 \mathrm{~mL}$ solid GEM medium (Eudes et al., 2003). These plates were also sealed with parafilm and placed in the growth chambers, under controlled conditions of photoperiod and temperature of 16 hours light and $22 \pm 2^{\circ} \mathrm{C}$, respectively.

The regenerated green seedlings were transferred to test tubes containing the rooting medium under identical conditions (Eudes et al., 2003). After showing two or three leaves and a well-developed root system, the plants were individually transplanted to vermiculite with identical growth conditions to those of the donor plants. As the albino plants developed, they were removed from the regeneration medium and counted. 
A group of ten spikes from each genotype was used for microspore extraction and purification. Based on the availability of spikes from each genotype, between four to nine extraction groups were formed for each genotype. Each small Petri dish consisted of one experimental unit, and the number of replicates for each genotype varied according to the number of extractions, which was from four to nine. The experiments were arranged in a completely randomized design.

The number of embryos, and green and albino plants were registered for each genotype, compared, and analyzed using the CoStat statistical software (Cohort Software, 2003) and the non-parametric Kruskal-Wallis test, at $5 \%$ probability, considering the means obtained for each genotype.

\section{Results and Discussion}

The different responses between genotypes confirm that the production of haploids through androgenesis is "genotype-dependent". Based on the Kruskal-Wallis test, at 5\% probability, a significant difference was observed between genotypes in terms of embryo formation $(\mathrm{H}$-test $=12.582$; degrees of freedom $=5$; $\mathrm{p}=0.027$ ). Embrapa 27 produced the lowest number of embryos and showed intense recalcitrance (Figure 1). Curiously, Frontana, and Sumai 3 produced more embryos, even than Fielder, usually considered the responsive control to androgenesis (Scagliusi, 2014). Fielder, BRS 179, and BRS 194 generated 37.5, 27.4, and 24.3 embryos per spike, respectively, revealing moderately responsive behavior. The high mean of 109.8 embryos per spike found here for Frontana was also reported in another similar research (Weigt et al., 2012), which assessed Polish wheat genotypes with different agronomic profiles. These authors found that the genotypes with the highest androgenic responses were those resistant to Fusarium, including Frontana and Sumai 3.

In the present study, the variations in androgenic response were affected by the genotype and the developmental stage of the microspore cells during spike collection. Taking this stage into account is a critical factor for the favorable outcome of the procedure; in most researches, cell purification is carried out with microspores in the intermediate-to-late uninucleate phase, when their susceptibility to exhibit totipotency is high (Dunwell, 2010; Germanà, 2011). Since the developmental cycle of most microspore cells within anthers is asynchronous, it is essential to select the spikes with the maximum number of embryogenic microspores, in order to ensure the success of the technique (Dwivedi et al., 2015). The relatively medium-to-low response verified for Fielder in the present study could be explained by the fact that only the first few spikes were observed under an optical microscope, leading to the misidentification of the developmental stage of the microspore. This can affect the expression of totipotency, since certain genes are only expressed during the initial developmental stages (Touraev et al., 1997), allowing the cells to respond to external stimuli and reprogram their developmental path from gametophytic to sporophytic, which may
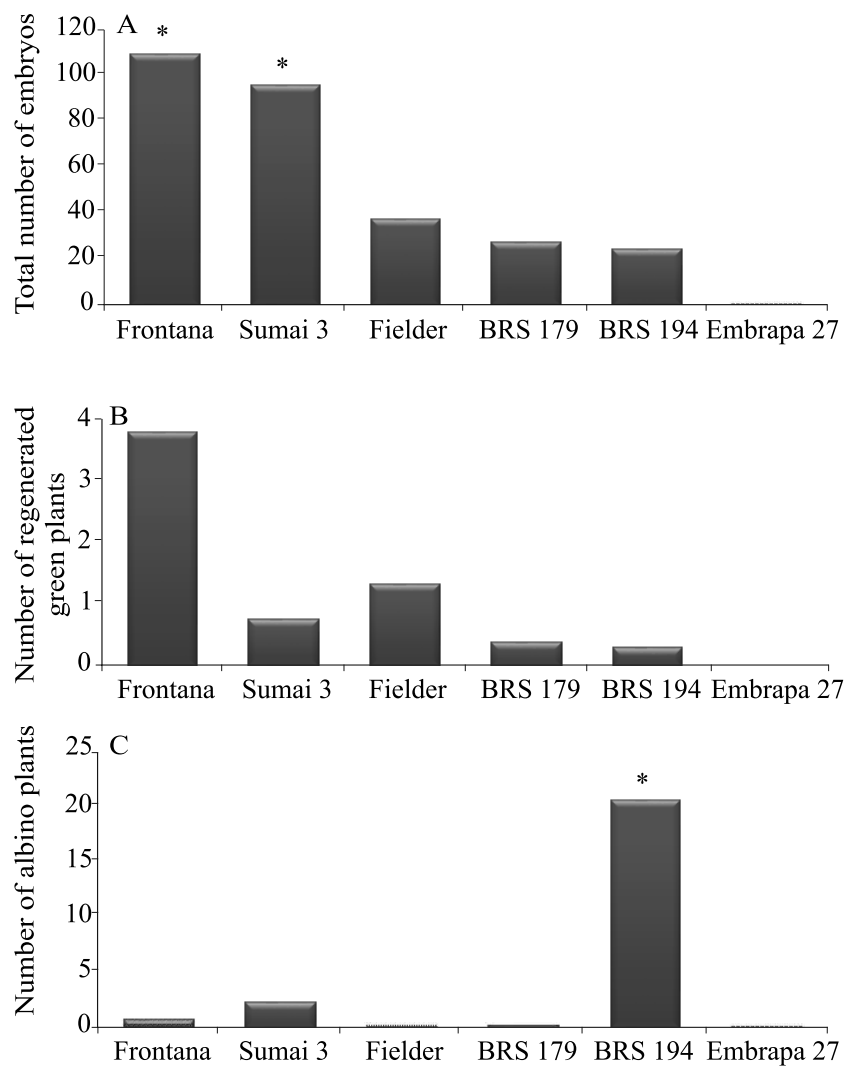

Figure 1. Mean of total number of embryos (A), regenerated green plants (B), and albino plants (C) obtained by spike via isolated microspore culture of six wheat (Triticum aestivum) genotypes. *Significant differences for each characteristic by the Kruskal-Wallis test, at $5 \%$ probability. 
have partially occurred for Fielder. It should be noted that, although morphological indicators may indicate the suitable phase for spike collection, only microscopic observation allows its proper identification.

Various types of pretreatments have been reported to trigger androgenesis. Most combine low or high temperatures with osmotic shock caused by carbohydrate and nitrogen deprivation (Touraev et al., 1997; Islam \& Tuteja, 2012). In the present study, low temperature shock was used to trigger androgenesis: the groups of spikes were maintained at $4{ }^{\circ} \mathrm{C}$ for a different number of days (17 to 31$)$. It should be highlighted that embryogenic response was not affected by this variation, since positive results were obtained throughout this period. Cold pretreatment alone was able to induce positive results in five out of the six tested genotypes; the exception was Embrapa 27, which showed the lowest response, a reaction already expected for this genotype, which is recalcitrant to androgenesis.

A minimum density of viable cells is also necessary to guarantee the induction of androgenesis in the microspores, as only a group of cells would react to the pretreatment stimulus. The findings of the present study revealed a high generation of purified cells for all tested genotypes, and the cell density used for each replicate was $7-8 \times 10^{4} \mathrm{~mL}^{-1}$ cells (Figure $2 \mathrm{~A}$ ). After an incubation period of 7 to 9 days in the NPB 99 semi-liquid extraction medium in the dark, at $27^{\circ} \mathrm{C}$, the uninucleated microspores were seen floating, and the large and single vacuole was subdivide into many smaller ones, producing a fibrillar structure with a star-

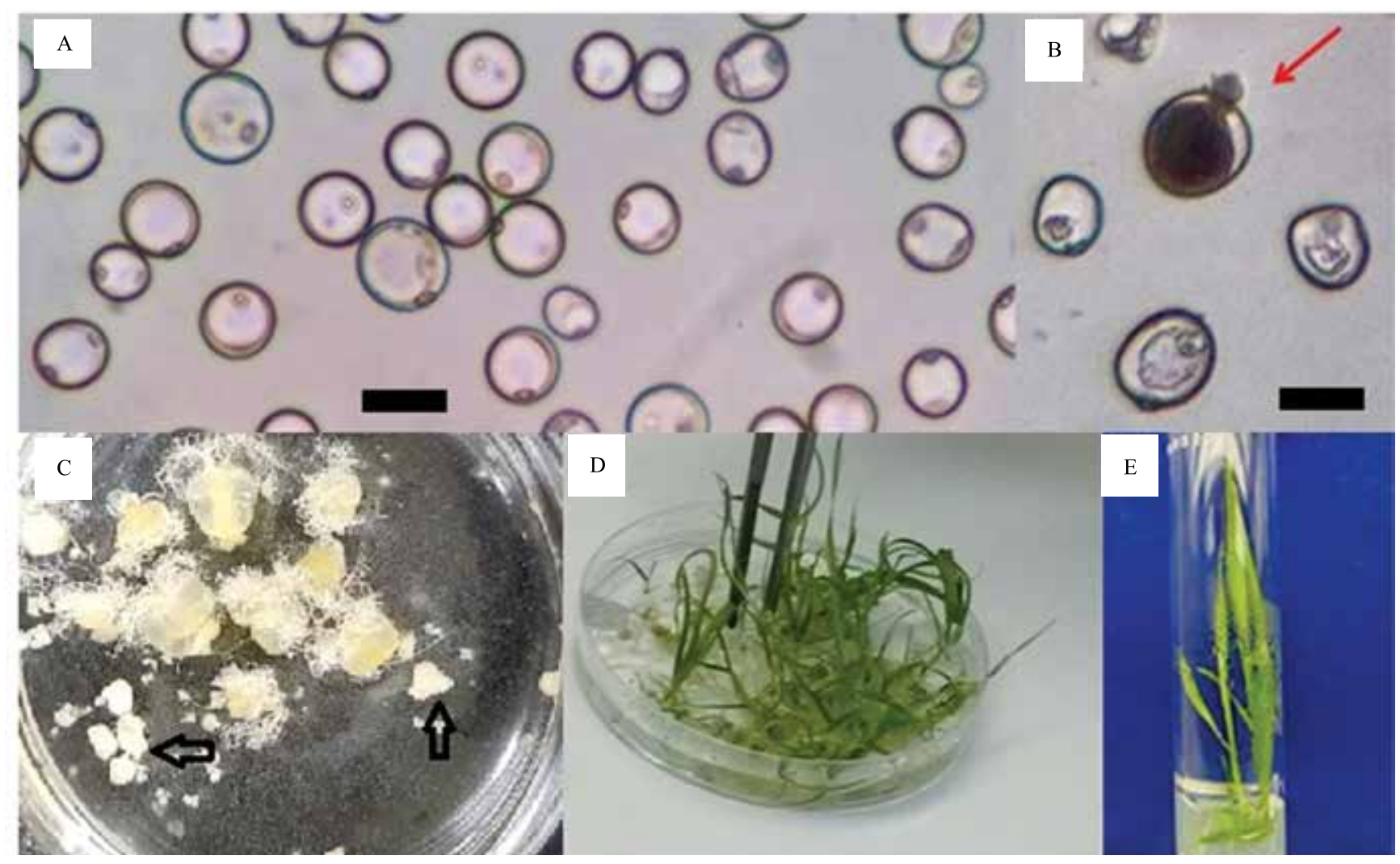

Figure 2. Purified uninucleate microspores (A); developing multicellular structure at 20 days, rupturing the exine for embryo formation, marked by arrow (B); embryo development in the induction medium (arrows), in the presence of ten mature ovaries (C); embryos regenerating green and albino plants (D); and green plant obtained via isolated microspore culture ready to be transplanted to vermiculite (E). Bar represents $70 \mu \mathrm{m}$. 
like feature, which has been previously reported as a representative morphology of totipotent cells (Seifert et al., 2016). Immediately after this phase, the first divisions were observed, although, in most genotypes, it occurred 20 days post-incubation.

The co-cultivation of microspore cells with live ovaries is another critical aspect for inducing microspore embryogenesis (Figure $2 \mathrm{C}$ ). The obtained results showed that the ovary-donor genotype strongly affected androgenic response (Figure 3). The presence of live ovaries enabled the microspores to achieve their embryogenic potential, and, when placed in the culture medium, the number of embryos and regenerated plants tends to increase significantly (Lippmann et al., 2015), even in less responsive or recalcitrant genotypes. Auxin-like substances or cell division-inducers like biopolymers, known as arabinogalactans, seem to be involved in the increase of androgenic response (Lippmann et al., 2015). Live ovaries behave as sources of crucial signaling molecules, which are slowly liberated during cell culture. This, in turn, maintains and extends the embryogenic potential induced during the spike pretreatment. Several reports show that ovary co-culture is vital to trigger embryo production, even for wheat genotypes responsive to the androgenic process (Scagliusi, 2014; Castillo et al., 2015).

Although high embryo production rates were observed for Frontana, Sumai 3, Fielder, BRS 179, and BRS 194, only a small proportion regenerated into green plants (Figure 1); therefore, no significant differences were found between genotypes for green

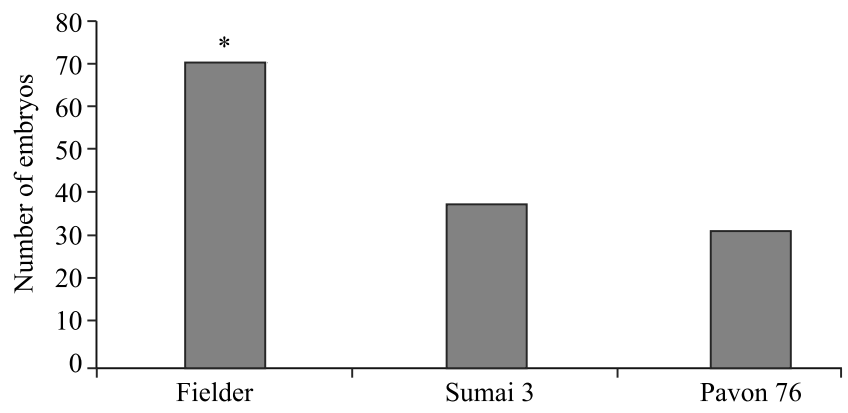

Figure 3. Mean number of embryos obtained by genotype via isolated microspore culture using three wheat (Triticum aestivum) genotypes as ovary donors for the co-culture of the microspore cells. *Significant differences for the number of embryos using the Kruskal-Wallis test, at 5\% probability. plants. These findings indicate an alteration in the microspore cell developmental pathway, creating the multicellular structures that became embryos (Figure 2 B); only a small percentage of these embryos sustained cell division, resulting in a poor regeneration rate. This implies in the presence of two distinct mechanisms controlling the induction and regeneration phases, responsible for embryo and plant formation, respectively. Broughton (2008) obtained similar results for the Datatine wheat cultivar, which induced 35.9 embryos per spike, but produced only three green plants. These data explain, at least in part, the multifactorial nature of androgenic response, showing that the efficiency of the androgenic process is linked to different independent factors, all of them regulated by nuclear inheritance and separated by genetic control (Krzewska et al., 2012). However, some degree of the regeneration competence is also affected by environmental and/or exogenous factors, which implies that improved responses could be achieved if the spike stress treatments or the composition of the culture media were modified (Liu et al., 2002). Prior knowledge of these types of responses would enable the manipulation of specific steps in the protocol, aiming to overcome usual constraints.

The regeneration of plants from unfertilized gametes is a complex process affected by several endogenous and exogenous factors, and, during which, some genotypes could routinely produce albino plants instead of green ones. This is a very common characteristic in the formation of doubled haploids through androgenesis, particularly in cereals (Makowska \& Oleszczuk, 2014). The present study showed significant differences between genotypes regarding the formation of albino plants $(H=19,449)$, at $5 \%$ probability. BRS 194 stood out with an average of 20.7 albino plants per spike, followed by Sumai 3 with 2.4 albino plants per spike. Because of its medium-to-high androgenic response, generating up to 95 embryos per spike, the response of Sumai 3 could be optimized by modifying the exogenous factors that interfere in the formation of green plants. The occurrence of albinism could possibly be connected with one or more combined factors, such as: genotype, growing conditions of donor plants, hormone imbalance, incompatibility between the nuclear and plastid genomes, deletions in the plastid DNA, mutations in the genes responsible for chlorophyll biogenesis, and a metabolic block in the 
pathways leading to chlorophyll biosynthesis. In this context, small changes in the protocol could promote positive outcomes. The addition of copper sulphate to the pretreatment solution and to the culture media, for example, has resulted in a significant reduction in the rate of albino plants (Sriskandarajah et al., 2015). The findings of the present study show that, even though all tested genotypes produced albino plants, albinism did not prevent the development of doubled-haploid plants from fusariosis resistant-genotypes. This opens up the possibility of adopting isolated microspore culture for the speedy introgression of disease-resistant genes. The use of haploidization in studies aiming to identify and validate fusariosis-resistant genes has been steadily increasing, reflecting the significance of this method in addressing this issue (Weigt et al., 2012; Kalih et al., 2015; Nishio et al., 2016). However, improvements have to be made in microspore culture protocol in order to be amenable to a wide range of genotypes, minimizing recalcitrance and albinism.

\section{Conclusions}

1. The Frontana and Sumai 3 wheat (Triticum aestivum) genotypes present the highest rates of androgenic response and can be used for the introgression of genetic resistance to fusariosis via isolated microspore culture.

2. Androgenic response is greatly impacted by ovary-donor genotypes, particularly Fielder, which positively affects embryo induction.

3. The formation of albino plants is common for BRS 194, Sumai 3, Frontana, BRS 179, and Fielder, but does not prevent responsive genotypes from being explored in wheat breeding programs for the development of cultivars resistant to fusariosis.

4. No significant differences are observed for green plant generation between genotypes.

\section{Acknowledgments}

To Coordenação de Aperfeiçoamento de Pessoal de Nivel Superior (Capes), for the scholarship granted to the master's student participating in this study; and to Professor Florindo Castoldi from Universidade de Passo Fundo, for the support with the statistical methods and data analyses.

\section{References}

BROUGHTON, S. Ovary co-culture improves embryo and green plant production in anther culture of Australian spring wheat (Triticum aestivum L.). Plant Cell, Tissue and Organ Culture, v.95, p.185-195, 2008. DOI: 10.1007/s11240-008-9432-7.

CASTILLO, A.M.; SÁNCHEZ-DÍAZ, R.A.; VALLÉS, M.P. Effect of ovary induction on bread wheat anther culture: ovary genotype and developmental stage, and candidate gene association. Frontiers in Plant Science, v.6, art.402, 2015. DOI: 10.3389/fpls.2015.00402.

COHORT SOFTWARE. Graphics and statistics software for scientists and engineers. Monterey, 2003.

DUNWELL, J.M. Haploids in flowering plants: origins and exploitation. Plant Biotechnology Journal, v.8, p.377-424, 2010. DOI: 10.1111/j.1467-7652.2009.00498.x.

DWIVEDI, S.L.; BRITT, A.B.; TRIPATHI, L.; SHARMA, S.; UPADHYAYA, H.D.; ORTIZ, R. Haploids: constraints and opportunities in plant breeding. Biotechnology Advances, v.33, p.812-829, 2015. DOI: 10.1016/j.biotechadv.2015.07.001.

EUDES, F.; ACHARYA, S.; LAROCHE, A.; SELINGER, L.B.; CHENG, K.-J. A novel method to induce direct somatic embryogenesis, secondary embryogenesis and regeneration of fertile green cereal plants. Plant Cell, Tissue and Organ Culture, v.73, p.147-157, 2003. DOI: 10.1023/A:1022800512708.

GERMANÀ, M.A. Anther culture for haploid and doubled haploid production. Plant Cell, Tissue and Organ Culture, v.104, p.283300, 2011. DOI: 10.1007/s11240-010-9852-z.

ISLAM, S.M.S.; TUTEJA, N. Enhancement of androgenesis by abiotic stress and other pretreatments in major crop species. Plant Science, v.182, p.134-144, 2012. DOI: 10.1016/j. plantsci.2011.10.001.

JÄHNE, A.; LÖRZ, H. Cereal microspore culture. Plant Science, v.109, p.1-12, 1995. DOI: 10.1016/0168-9452(95)04149-O.

JESUS JÚNIOR, C. de; SIDONIO, L.; MORAES, V.E.G. de. Panorama das importações de trigo no Brasil. BNDES Setorial, n.34, p.389-420, 2011.

KALIH, R.; MAURER, H.P.; MIEDANER, T. Genetic architecture of Fusarium head blight resistance in four winter triticale populations. Phytopathology, v.105, p.334-341, 2015. DOI: 10.1094/PHYTO-04-14-0124-R.

KRZEWSKA, M.; CZYCZYŁO-MYSZA, I.; DUBAS, E.; GOŁĘBIOWSKA-PIKANIA, G.; GOLEMIEC, E.; STOJALOWSKI, S.; CHRUPEK, M.; ZUR, I. Quantitative trait loci associated with androgenic responsiveness in triticale (x Triticosecale Wittm.) anther culture. Plant Cell Reports, v.31, p.2099-2108, 2012. DOI: 10.1007/s00299-012-1320-2.

LANTOS, C.; WEYEN, J.; ORSINI, J.M.; GNAD, H.; SCHLIETER, B.; LEIN, V.; KONTOWSKI, S.; JACOBI, A.; MIHÁLY, R.; BROUGHTON, S.; PAUK, J. Efficient application of in vitro anther culture for different European winter wheat (Triticum aestivum L.) breeding programmes. Plant Breeding, v.132, p.149-154, 2013. DOI: 10.1111/pbr.12032. 
LIPPMANN, R.; FRIEDEL, S.; MOCK, H.-P.; KUMLEHN, J. The low molecular weight fraction of compounds released from immature wheat pistils supports barley pollen embryogenesis. Frontiers in Plant Science, v.6, art.498, 2015. DOI: 10.3389/ fpls.2015.00498.

LIU, W.; ZHENG, M.Y.; POLLE, E.A.; KONZAK, C.F. Highly efficient doubled-haploid production in wheat (Triticum aestivum L.) via induced microspore embryogenesis. Crop Science, v.42, p.686-692, 2002. DOI: 10.2135/cropsci2002.0686.

LU, R.; CHEN, Z.; GAO, R.; HE, T; WANG, Y.; XU, H.; GUO, G.; LI, Y.; LIU, C.; HUANG, J. Genotypes-independent optimization of nitrogen supply for isolated microspore cultures in barley. BioMed Research International, v.2016, art.1801646, 2016. DOI: $10.1155 / 2016 / 1801646$.

MAHESHWARI, P.; EUDES, F. Genetic engineering and precision editing of triticale genomes. In: EUDES, F. (Ed.). Triticale. Cham: Springer, 2015. p.141-163. DOI: 10.1007/978-3319-22551-7_8.

MAKOWSKA, K.; OLESZCZUK, S. Albinism in barley androgenesis. Plant Cell Reports, v.33, p.385-392, 2014. DOI: 10.1007/s00299-013-1543-x.

NISHIO, Z.; ONOE, C.; ITO, M.; TABIKI, T.; NAGASAWA, K.; MIURA, H. Mapping a QTL conferring resistance to Fusarium head blight on chromosome $1 \mathrm{~B}$ in winter wheat (Triticum aestivum L.). Breeding Science, v.66, p.668-675, 2016. DOI: 10.1270/jsbbs.16097.

NIWA, S.; KUBO, K.; LEWIS, J.; KIKUCHI, R.; ALAGU, M.; BAN, T. Variations for Fusarium head blight resistance associated with genomic diversity in different sources of the resistant wheat cultivar 'Sumai 3'. Breeding Science, v.64, p.90-96, 2014. DOI: 10.1270/jsbbs.64.90.

OLIVEIRA NETO, A.A. de; SANTOS, C.M.R. (Org.). A cultura do trigo. Brasília: Conab, 2017. 218p. Available at: <http://www. conab.gov.br $\geq$. Accessed on: June 192017.
PARRY, D.W.; JENKINSON, P.; MCLEOD, L. Fusarium ear blight (scab) in small grain cereals - a review. Plant Pathology, v.44, p.207-238, 1995. DOI: 10.1111/j.1365-3059.1995.tb02773.x.

SCAGLIUSI, S.M. Establishing isolated microspore culture to produce doubled haploid plants in Brazilian wheat (Triticum aestivum L.). Australian Journal of Crop Science, v.8, p.887894, 2014.

SEIFERT, F.; BÖSSOW, S.; KUMLEHN, J.; GNAD, H.; SCHOLTEN, S. Analysis of wheat microspore embryogenesis induction by transcriptome and small RNA sequencing using the highly responsive cultivar "Svilena". BMC Plant Biology, v.16, art.97, 2016. DOI: 10.1186/s12870-016-0782-8.

SRISKANDARAJAH， S.; SAMERI， M.; LERCETEAUKÖHLER, E.; WESTERBERGH, A. Increased recovery of green doubled haploid plants from barley anther culture. Crop Science, v.55, p.2806-2812, 2015. DOI: 10.2135/cropsci2015.04.0245.

TOURAEV, A.; VICENTE, O.; HEBERLE-BORS, E. Initiation of microspore embryogenesis by stress. Trends in Plant Science, v.2, p.297-302, 1997. DOI: 10.1016/S1360-1385(97)89951-7.

WEIGT, D.; NAWRACAŁA, J.; POPOWSKA, D.; NIJAK, K. Examination of ability to androgenesis of spring wheat genotypes resistant to Fusarium. BioTechnologia, v.93, p.116-122, 2012.

ZADOKS, J.C.; CHANG, T.T.; KONZAK, C.F. A decimal code for the growth stages of cereals. Weed Research, v.14, p.415-421, 1974. DOI: 10.1111/j.1365-3180.1974.tb01084.x.

Received on May 3, 2017 and accepted on August 28, 2017

Pesq. agropec. bras., Brasília, v.53, n.5, p.575-582, May 2018

DOI: 10.1590/S0100-204X2018000500006 